\title{
1. Summons to a new axial age: the promise, limits and future of the Earth Charter
}

\section{J. Ronald Engel}

\section{INTRODUCTION}

The question before us is how to build an international movement with the power to usher in a new era of global governance in which justice and peace prevail and the ecological integrity of the planet is restored and sustained. This is the overarching question in terms of which we need to address the strengths, limitations and prospects of the Earth Charter in its role as a creative catalyst for the social movements of our time.

In keeping with the vision of the Earth Charter, I assume that the means and the end of the new era of global governance which we seek are democratic at their core: it is "we, the peoples of the world," who are sovereign and bear the moral obligation for personal, political, economic and ecological self-government that is free, equal, communal and sustainable. Social movements have a paramount role in realizing this vision of democratic Earth governance.

It is time that we who affirm the Earth Charter as the standard bearer for a world-changing movement for global citizenship, who have sought to gain support for the Charter and implement its principles in diverse political, cultural and intellectual contexts, step back and ask whether the public identity, text and strategy of the Charter are adequate to catalyze and guide the "great work" required of us in the twenty-first century.

I pose this challenge as a member of the core drafting committee of the Earth Charter. Through my scholarly activity and association with religious communities and the World Conservation Union, I have sought to advance the Charter in the years since its official launch in $2000 .{ }^{1}$ The critique that

1 Klaus Bosselmann and J. Ronald Engel (eds), The Earth Charter: A Framework for Global Governance (KIT Publishers, 2010); J. Ronald Engel, “A Covenant Model 
follows is offered in the spirit of self-reflective criticism and critical loyalty to my comrades in the Earth Charter movement and the vocation we share. My approach is well stated by environmental philosopher Strachan Donnelley:

Many of us believe that the full power and real significance of the Earth Charter will be realized by considering it as an interpretative text rather than a final consensus document. The Charter recurrently calls us back to re-ask and re-explore its fundamental animating questions. What are our deepest responsibilities to the Earth and its inhabitants, human and other? Why? In this questing and questioning spirit, I briefly want sympathetically, but critically, to push the Charter further along what I take to be its intended path. ${ }^{2}$

The argument that informs my critique has taken shape over the last decade in response to the world events that have occurred since the launch of the Charter in 2000 and the painful realities of our deteriorating global situation, and what they tell us regarding the radical changes in human aspiration and action that are required if human and other life is to survive with dignity on our planet.

The burden of this argument is that if we are to realize the true promise of the Earth Charter and the movement that supports it, we must use the text as a platform for reinvigorating the discussion of global ethics that created it and be much more explicit about the societal transformations that will be required to implement its underlying vision and principles than we have so far been. As things now stand, neither the Earth Charter text by itself nor the strategy of endorsement we have largely pursued for its acceptance and implementation is sufficient to catalyze an international movement with power to usher in a new era of global governance. But the conceptual and social foundations for such a movement are in fact available to us. While the Charter text shies away from explicit advocacy of such revolutionary principles as those of equality, redistribution of wealth, limits to growth, population reduction and organized political resistance that are required to challenge and replace the contemporary unjust, unsustainable and violent international order, it announces strong abstract principles of ecological integrity, economic and social justice and non-violence that fundamentally challenge that order. Furthermore, there is every evidence that many, if not most Earth Charter leaders and supporters are practically committed to such principles. The challenge of a renewed, deepened and expanded debate on how the Charter's text needs to be supplemented

of Global Ethics" (2004) 8(1) Worldviews: Environment, Culture, Religion 29-46; J. Ronald Engel, "Property: Faustian Pact or New Covenant with Earth?" in D Grinlinton and Prue Taylor (eds.), Property Rights and Sustainability (Martinus Nijhoff, 2004) 63-86.

2 Strachan Donnelley, "Chartering the Earth for Life's Odyssey" (2004) 8(1) Worldviews: Environment, Culture, Religion 93. 
and on what should be our practical agenda for social change is therefore very much in order.

The Earth Charter should be considered a step - an important step - in the process of finding common ground and a new revolutionary democratic and ecological worldview; but it is a step that needs to continue to evolve and take force through ongoing dialogue and action.

In no way should anything that I say be interpreted to mean a rejection of the Earth Charter itself or a negative criticism of the work of the members of the Earth Charter Initiative, Council or Commission. Far from it! Honest debate is not disparagement, but the highest tribute. Whatever the failures in our work, they are our collective failures as members of the Earth Charter movement. Indeed, what I argue here only makes the work of the Earth Charter Initiative and its supporters, especially among the world's dissenting social movements, more important and deserving of support.

An adequate assessment requires a number of steps that can only too briefly and incompletely be taken here. The first is to clarify the fundamental vision of the world on behalf of which we are called to bear witness, the normative baseline in terms of which we need to assess all aspects of the world today and to which we therefore must hold ourselves and the Earth Charter accountable. The second step is to judge how adequately we have justified and promoted its moral authority and allegiance to this worldview. The third step is to judge the adequacy and sufficiency of the Earth Charter text in light of the state of the planet and the forces that are driving, or resisting, the spiraling destruction of human dignity and ecological integrity. The fourth is to propose an agenda of work of the size required if we are to realize the promise of the Charter in world history.

\section{A NEW AXIAL AGE}

The vision of a new global era of realized Earth community is variously described and named across the world today. Playing off the famous thesis of Karl Jaspers, North American theological ethicist Douglas Sturm proposes that the Earth Charter is a summons to a new axial age, when the vision of the sacredness of human life and a universal human community announced by the prophets of the first axial age (Confucius, Lao-Tzu, the Upanishads, the Buddha, Zarathustra, Plato, Isaiah, Jeremiah and Jesus of Nazareth) is incorporated into the vision of an even more comprehensive universal community, the sacredness of the community of life. ${ }^{3}$ The first axial age laid the moral and

3 Douglas Sturm, "Identity and Alterity: Summons to a New Axial Age" (2000) 1(2) Journal of Liberal Religion: An Online Theological Journal, www.meadville.edu. 
spiritual groundwork for many subsequent affirmations of radical democratic human freedom, equality and solidarity. The second axial age, now coming into the foreground of human moral possibility, dares to extrapolate those principles from their intra-human context to our relationships with other species and the Earth, envisioning a time when we may extend to nature a fundamental liberty and equality, when we may co-exist with all species in solidarity on the shared commons of our planet.

The prospect of a new axial age is new only in the sense that it is a seasonally relevant recovery of the truth of who we and the rest of life most essentially are, and as such a timely prophetic declaration of the universal ethical laws in terms of which we ought to pattern our lives. It is not a matter of the idealizing human imagination, a utopian vision or a matter of human preference, but a firmer grasp of the truth of moral and physical natural law that stands in judgment of every finite and limited human understanding and practice. Its ultimate justification therefore is unabashedly ontological.

To premise that we have access to the essential structure of reality and its moral requirements is also to claim that we are capable of self-government for the common good of the Earth community in keeping with the natural laws of our physical and moral being by virtue of our inherent capacities for reason, persuasion and moral choice. These inherent and shared powers make us members of one moral community and place upon us the obligation to develop through rational deliberation a set of shared values, including shared rights and duties, by which to order our global existence.

The ontology that underlies this dialogical doctrine of human nature and the vision of a new axial age is defined by Sturm as the principle of internal relations "according to which relations are not extraneous to an agent; they are, in important ways, constitutive, albeit not wholly determinative, of an agent's being and character." In the midst of this interplay between interdependency and autonomy, we find whatever is of value in existence, are brought to affirm the intrinsic value of all beings and are provoked to assess how well that intrinsic value is honored. His account is representative of a wide range of contemporary philosophical, theological and scientific judgments regarding the fundamental relational character of our existence:

We are, in our fundamental reality, relational beings, co-creators of an evolving universe, bestowed by our inheritance with the special powers of humankind, and therefore held responsible, so far as we are capable, for the flourishing of the entire community of life - in part, at least, for the sake of our own flourishing. That is our calling and, we might say, that is our appointed destiny. ${ }^{4}$

4 Ibid. 
We can see how the vision of a new axial age is instructed by Native peoples who celebrate gratitude for the gift of the covenanted community of life, so well evidenced by the thanksgiving prayer of the Iroquois prophet, the Peacemaker. It is indebted to the revolutionary struggles of all those who over the centuries have sought to "turn the world upside down" by resisting the enclosures of the commons. It was announced by foresighted individuals and communities who bore personal witness to it over the last century - from Hannah Arendt to Mohandas Gandhi, Martin Luther King, Jr., Aung Sang Suu Kyi, Andrei Sakharov, Vaclav Havel, Nelson Mandela, Chico Mendes, Ken Saro-Wiwa and Dorothee Soelle, to name only a few. And it is deeply informed by the natural sciences and those theories that emphasize the relational integrity of evolutionary and ecological processes.

\section{THE MORAL AUTHORITY OF THE EARTH CHARTER}

The Earth Charter may be interpreted as a summons to the great work of building the new axial age. "As never before in history," the Charter propounds in its concluding section, "common destiny beckons us. . . to seek a new beginning."

In distinction from most other declarations of global moral aspiration that concentrate exclusively on human community, such as the Universal Declaration of Human Rights, or the community of life apart from human beings, such as A Manifesto for Earth, the Earth Charter presents a fully comprehensive and holistic account of our interdependent social and ecological responsibilities, a defining characteristic of the second axial age. As the Preamble reads: "To move forward we must recognize that in the midst of a magnificent diversity of cultures and life forms we are one human family and one Earth community with a common destiny."

The Preamble also makes it explicit that this is a declaration of the principles of responsible local and international self-government: it aims to speak for "we, the peoples of earth. . . at once citizens of different nations and of one world in which the global and local are linked." The body of the text articulates fundamental spiritual, ethical, ecological, social, economic and political principles of democratic self-government. It is not difficult to see a relational ontology in the foundational first principle:

1. Respect Earth and life in all its diversity.

(a) Recognize that all beings are interdependent and every form of life has value regardless of its worth to human beings.

(b) Affirm faith in the inherent dignity of all human beings and in the intellectual, artistic, ethical, and spiritual potential of humanity. 
Or to see how this worldview undergirds the major parts of the Charter Ecological Integrity; Social and Economic Justice; Democracy, Non-violence and Peace - by repeated affirmations not only that human wellbeing and social justice are priorities in their own right, but also that only through the elimination of poverty and other human deprivations and the establishment of just and non-violent social and economic relationships will the citizens of the world be in a position to protect and restore the integrity of Earth's ecological systems. Nor will there be any peace or security in a world of collapsing ecosystems, mass poverty, political oppression and economic injustice. Principle 3 - "Build democratic societies that are just, participatory, sustainable, and peaceful" - makes it clear that this is a substantive and not merely procedural vision of democracy; while Principle 13 - "Strengthen democratic institutions at all levels, and provide transparency and accountability in governance, inclusive participation in decision making, and access to justice" - articulates critical procedural elements required to realize the substantive vision.

This interpretation of the Charter's basic vision and loyalties, however, stands in considerable tension with the way we have largely gone about legitimating its moral authority. Whereas the Charter is founded on a claim to the truth of our created communal being and the rights and responsibilities that rationally follow, the Charter is publicized as a declaration whose authority is derived from international consensus on shared values. The claim that the Charter is the result of the most extensive international consultation ever conducted for a document of its kind is frequently put forward to justify its normative moral authority.

When I put myself back in the heady days of the 1990s, following the Rio Earth Summit and the end of the Cold War, when we seemed to be riding the crest of a wave for growing international cooperation on issues of the environment and sustainable development, and we dared to hope that the Charter might be further negotiated and endorsed by the United Nations General Assembly in the new millennium, it is easy to see how the effort to show that there was agreement on what by most counts was a very positive agenda for the future of the planet could become the uppermost consideration in our thinking. In the background was the vague assumption that the wave we were riding was in some sense a culmination of many earlier waves that had propelled humanity forward in the course of its modern Enlightenment and liberation. There was also the hard lesson of the Rio Summit: proposals for an Earth Charter that go too far in challenging the neo-liberal economic regime fail to secure the endorsement of the United Nations. The argument that we urgently need a shared vision of basic values to provide an ethical foundation for the emerging world community, with subsequent appeals to cooperation in an interdependent world that faces common crises, readily became uppermost in our minds. 
The temptation to which we fell prey was then to believe that the Charter is the product of a neutral communicative process; the expression of what is already a latent global consensus; the unbiased result of a totally inclusive and open deliberative engagement. In our enthusiasm for the vision, all the disagreements that divide the world and form the lifeblood of violent conflict faded away. We overlooked the inconvenient fact that the world is being destroyed because very specific persons and organizations are deliberately destroying it for their own advantage, and that they will stop only when greater power is organized in opposition to them. Someone looking in at the Earth Charter from outside its immediate committed constituency might be understandably put off by what appears at times to be an assumption of universal consensus and the promise of conflict-free earthly redemption. Thus, the brochure distributed upon the launch of the Charter in 2000 explains that the sources of the text include contemporary science (as though this constituted one teaching), a codification of international law (as though this were entirely positive), the common teachings of indigenous peoples and the world's great religious and philosophical traditions (again, as though this constituted one teaching), the many declarations and reports of United Nations conferences, the global ethics movement, numerous non-governmental declarations and the best practices for building sustainable communities. This conceptual utopia in which everyone agrees with everyone else is visually underscored by pictures of multi-racial smiling faces ringing a peaceful sylvan landscape replete with deer and waterfalls.

The emphasis upon agreement risks adopting a methodological pragmatic outlook wherein "truth" is considered primarily a matter of "agreement," not of objective evidence and rational argument, and the sacrifice of principle is assumed to be sometimes necessary for the sake of harmony of opinion and cooperation in action. The Charter's stance here is endemic to contemporary liberalism, which has turned its back on natural law and adopted in its stead a Rawlsian contract ethic whereby representatives of differing social locations, by absenting themselves from their actual situations and imagining themselves anyone anywhere, can come to agree on certain abstract practical principles. In the background is the notion that the problems we face are due primarily to the ethical partiality that is rooted in personal attachments to class, identity, nation, religion or place; and that we therefore need to ascend to some universal perspective which will give us a view from everywhere which is really a view from nowhere.

In my sober moments, I recognize that the vision of the Earth Charter stands in radical disjunction from the headlines I see screaming at me from each morning's newspaper. The Charter expresses not a majority consensus, but a minority worldview we desperately want to become a consensus of the majority. As matter of fact, the drafting committee began its work with a set of 
substantive values and in my experience largely consulted persons and groups likely to share those values. But in our rush to legitimacy by the assertion of universal consensus, we risked losing the very moral authority on the basis of which our position might someday become a meaningful consensus. The committee that Eleanor Roosevelt gathered to draft the Universal Declaration of Human Rights had no illusion after the horrors of the Second World War that it represented humanity's actual values. The committee wrote on behalf of an age-old cause for which history provided a rare opportunity for success. ${ }^{5}$

Some of the most outspoken fundamentalist critics of the Earth Charter, who claim that it represents in some sense a new religion or substantive faith, are actually right. They are vastly in error regarding the nature of the faith, seeing in it a pagan worship of Earth and a conspiracy to establish a totalitarian global government. But they are right in seeing that the central vision the Charter bears is an ontological claim to what is worthy of our ultimate commitment and therefore in the largest sense a reasoned and prophetic faith. Earth Charter advocates such as myself often evoke the way the beliefs of a plurality of "faith communities" are sources for the principles of the Charter. This claim is justified. But it also conveniently avoids controversy by setting "faith" at arm's length from the Charter, sidestepping claims that the Charter itself expresses our ultimate allegiance.

\section{STATE OF THE WORLD}

Thirteen years after the launch of the Earth Charter in 2000, it is evident that a great work is under way. Unfortunately, it is not the one called for by the new axial age.

This is not the place to give a detailed report on the state of the world. "The Global Situation" in the Preamble of the Earth Charter accurately describes our situation - only it is much worse. Since the Charter was written, climate change has not only become a matter of wide international concern, but also accelerated at an unexpected rate; habitats are in more precipitous decline; per capita income difference within most nations and between rich and poor countries has grown dramatically; world population continues to expand; military conflict, causalities and expenditures have increased manifold; and greenhouse gas loading of the atmosphere, nitrogen pollution, ozone layer depletion and loss of biological diversity are exceeding planetary boundaries at such speed that some argue the planet may be poised to undergo an imminent,

5 Mark Mazower, Governing the World: The History of an Idea (Penguin, 2012). 
human-induced state shift. ${ }^{6}$ This is the place, however, to speak about the principal causes of this downward spiral.

I find it irrefutable that the primary agencies responsible are corporate economic interests in alliance with government and military interests (the so-called "military-surveillance-police state industrial complex") that have successfully seduced the masses of world citizens - the same interests that have, since the beginning of the modern era, successfully colonized, privatized and enclosed the natural and cultural commons of the planet and built a hierarchy of wealth, power and privilege that now effectively governs our world civilization. The ideologies that have enabled this exploitation to succeed - as most readers of this chapter will recognize - include the fantasy of unlimited expansion of economic activity and population in a world without limits; the dogma that unregulated private "free market" organization of economic life is the only kind that is practicable, regardless of the human or ecological consequences; and the belief that we are engaged in a war against nature and against one another, and we must dominate others or be dominated by them. It is no wonder that we are witnessing demoralization throughout the environmental, human rights and peace action communities as the tenuous achievements of responsible governmental and non-profit agencies are repeatedly dismantled by the "shock doctrine" administered by greed in league with brutal military force. $^{7}$

The greatest limitation of the Earth Charter text in my view is its lack of any account of the actual powers and ideologies that are responsible for the spiraling deterioration of the planet and any clear call to non-violent revolutionary resistance against them. Although we were successful in the drafting of the Charter on many fronts - explicitly noting that the finitude of the resources of the environment is an important concern, providing a significant phrasing of the precautionary principle, urging lifestyles of material sufficiency, advocating local community action for sustainability and calling for a "quickening" of the "struggle for justice and peace" - our overarching message was that we are all generally responsible for the plight of the planet and we can work together harmoniously to change the situation by voluntary choice. In retrospect, this now seems a remarkably comforting message for a privileged audience.

We stand in much the same situation in respect to the Earth Charter today as South Africans stand in respect to their "long walk" to realize the promise

6 Worldwatch Institute and Erik Assadourian, State of the World 2013: Is Sustainability Still Possible? (Island Press, 2013).

7 Naomi Klein, The Shock Doctrine: The Rise of Disaster Capitalism (Metropolitan Books, 2007). 
of the Freedom Charter. As T.O. Molefe wrote in the New York Times on the death of Nelson Mandela:

For all his remarkable achievements, Nelson Mandela died with his dream for South Africa incomplete. [Political] Democracy and justice were attained, yet real racial harmony, social justice and equality seem, in some ways, further away than ever. . . Today an economic revolution is what is needed most if South Africa is to continue on the path to reconciliation. ${ }^{8}$

To read the text of the Earth Charter, one would never know that we live in a world dominated by a corporatist global economy that has made the depletion of resources so rapid, convenient and barrier free that "earth-human systems" are becoming dangerously unstable in response; or that the profits from this depletion are backed up by nuclear weapons and drones; or that this has anything to do with violation of human rights, torture, repression of dissent, the sixth great mass extinction of species, or the corruption and dysfunction of the world's governments.

We omitted such matters because we believed the Earth Charter was a document about ethics, not politics or economics or social history. What we failed to see is that it is impossible to do serious ethics in a way that it is somehow "above" or "neutral" with regard to these subjects; and that by omitting such matters as the actual economic or military system under which we live, we in effect unconsciously consecrate it.

Equality is a fundamental principle of the religions and philosophies of the first axial age and the radical democratic promise of the new axial age. It is surely embraced by most Earth Charter advocates and social movements seeking to implement the vision of the Charter in public life. But for reasons I cannot explain or justify, "equality" is noticeably absent from the text of the Earth Charter. It appears only once in reference to gender relationships and is omitted at critical points which would appear to require it, as in Principle 1.b., which ideally should read: "Affirm faith in the inherent and equal dignity of all human beings. . ." The principle that replaces equality is "equity." Thus, Principle 10: "Ensure that economic activities and institutions at all levels promote human development in an equitable and sustainable manner;" and especially Principle 10.a: "Promote the equitable distribution of wealth within nations and among nations."

"Equity" suggests fairness and the obligation to remedy injustice, and this is clearly its intended meaning in the Earth Charter. It is also true that many of

8 T.O. Molefe, "Mandela's Unfinished Revolution" New York Times, December 13, 2013; www.nytimes.com/2013/12/14/opinion/molefe-mandelas-unfinished-rev olution.html. 
the imperatives of the Earth Charter, if implemented in social policy, would have the result of increasing equality. But without an explicit affirmation that judgments of fairness are made for the sake of honoring or achieving equality, we inadvertently leave the door open for entitlement theories of justice whereby persons have a right to whatever holdings they have acquired or have been transferred to them in keeping with positive legal principles. It would be contrary to that theory to redistribute holdings according to some strong deontological, utilitarian or historically justified principle of equality. This is an unfortunate substitution of terms in a declaration that admonishes us to build true democratic societies when millions of persons have sacrificed their lives for the classic revolutionary democratic ideal of "freedom, equality, and solidarity."

The substitution of "equitable" for "equal" is in keeping with our omission of any mention of "property" or "investment" or "profit" or "growth" as matters of direct ethical concern. Principle 2a begins: "Accept that with the right to own, manage, and use natural resources. .." On review, I find myself asking "What right? Whose right?" Those who now own them or have the means to own them in our current system of private property rights? How unobjectionable it sounds to speak of "the conduct of all individuals, organizations, businesses, governments, and transnational institutions" (a series repeated several times), to thus list for-profit "business" as simply one in a series of agencies, on par with any individual or group, and not a very special category of social organization, inclusive not only of street vendors, but also transnational corporations and elites whose assets outstrip the wealth of nations.

I can only conclude that as we set about drafting the Earth Charter in the 1990s, we tacitly assumed that profit-driven, corporate-dominated economic globalization would be the context in which the world would continue to produce, trade and consume for years to come, and that the aim of our text was to morally restrain and redirect it. Yes, we called for regulatory reforms: "10.d. Require multinational corporations and international financial organizations to act transparently in the public good, and hold them accountable for the consequences of their activities." And we had the courage to call for forgiveness of international debt. But the apparent presumption at the time was that equity and sustainability - if not outright equality - could be achieved without substantial redistribution of wealth within and across the nations of the world or reorganization of the global economic system at its roots. I no longer believe this is possible. My hope and conviction is that such redistribution can and should be achieved incrementally by progressive taxation, and by the development of new cooperative worker-owned economic enterprise within the shell of the prevailing economic system, without the violence and repressive authoritarianism that so often attends revolutionary change. 
The liberal pretense of separating ethics from the concrete specifics of social, political and economic reality leads to a particular understanding of this reality slipping unnoticed into our ethics. The fact that the Earth Charter USA adopted the "triple bottom line" of "people, planet and profit" as its criterion for its "Earth Charter Awards" demonstrates how easily this can be done.

If we are serious about answering the summons to the new axial age, we need to understand that the scientific and moral natural law that establishes its moral and practical demands must be complemented with clear identification of those powers and ideologies that need to be opposed and those that deserve to be the primary goals of the great work. A credible worldview or ontology requires a credible social analysis and history. Every ethical principle - implicitly or explicitly - is a personal, political and economic principle as well.

\section{ANSWERING THE SUMMONS}

By its forthright affirmation of the ontology of the community of life, the Earth Charter carries the grounds for its own critique. The summons to a new axial age as the truth of our being and not merely an idealistic aspiration is eloquently stated in the text, even as the text also displays the limited historical and social horizons of its authors. The Earth Charter and the many initiatives that have formed in its name are simply too important to the world to be abandoned. The examples set by the many leaders, named and unnamed, of the Earth Charter movement deserve our continuing support. Declarations such as the Earth Charter play an essential role in giving purpose and direction to human spiritual, moral and political aspirations. They are our contemporary jeremiads. We should not risk compounding the discouragement so many of us suffer when we honestly confront the state of the world with disillusionment over the failure of our efforts to adequately articulate and advance natural law principles of global ethics such as the Earth Charter. It is precisely because of the promise of the Earth Charter to inspire and guide the building of a just, sustainable and peaceful world that I have made this critique.

The Charter stands as the most comprehensive, widely endorsed declaration of the ontological and ethical foundations of the new axial age on the international stage. How can it now serve as a platform for building an international movement with sufficient power to dismantle the global economic system that is racing to exploit the ever-shrinking natural resources of the planet and in the process causing ecological havoc, unprecedented levels of inequality and increasing military conflict? How can it contribute to the great work of preserving and restoring the planet's ecological integrity with strategies of authentic sustainable development which will permit human communities to live within the physical and social limits of their bioregion and the planet? 
The saving grace is that, appearances sometimes to the contrary, neither the Earth Charter text nor its supporters claim to be providing a complete and final ethical blueprint for the planet in any dogmatic sense. The Charter concludes: "We must deepen and expand the global dialogue that generated the Earth Charter, for we have much to learn from the ongoing collaborative search for truth and wisdom."

Since the launch of the Earth Charter, numerous groups have issued comparable declarations of global ethics and have brought them before the public for debate and adoption. The draft citizen treaties prepared for the Rio+20 Summit in 2012 are important cases in point. Complementing this activity, we are also witnessing a near-simultaneous global "awakening" from Tahrir Square to Zuccotti Park, from Athens to Istanbul to Beijing and beyond. The time appears ripe to provide ethical direction to these often-inchoate popular protests, many of which are seeking to "prefigure" in their form of democratic self-organization the new axial age they aim to create.

The Earth Charter Initiative has an opportunity to convene a summit of leaders of the outstanding declarations of global ethics in current circulation for the purpose of reigniting the dialogue on global ethics and creating a global alliance with greater organizational power and influence than any can exercise independently. Most persons and groups who have endorsed the Earth Charter will likely welcome renewed dialogue and possibly a new document that supplements the Earth Charter text with a political, economic and scientific analysis of our contemporary situation and the actions that need to be taken to make the Charter a social reality. Among the issues to be discussed are the following:

(1) How do we go about the task of degrowth? How do we build a new economy of sustainability and equality to replace corporate capitalism? ${ }^{9}$ These are not new questions for Earth Charter dialogues. In the 2005 volume The Earth Charter in Action, Oscar Motomura of Brazil found that in order to unpack the meaning of Principle 10, he must introduce the value of "detachment" and ask the question of "how the peoples of the planet can join forces to ensure the total reinvention of the politico-economic-business system, both locally and globally so that everything is geared toward the common good, toward global well-being?"10 Numerous allies can be found for this great work today, including sponsors of global ethics declarations such as the "Universal

9 Burns H. Weston and David Bollier, Green Governance: Ecological Survival, Human Rights, and the Law of the Commons (Cambridge University Press, 2013).

10 Oscar Motomura, "The Earth Charter and the World of Business and Economics" in P. Corcoran, M. Vilela and A. Roerink (eds.), The Earth Charter in Action: Toward a Sustainable World (KIT Publishers, 2005) 100. 
Covenant Affirming a Human Right to Commons- and Rights-based Governance of Earth's Natural Wealth and Resources" by the Commons Law Project.

(2) "Principle 5. Protect and restore the integrity of Earth's ecological systems, with special concern for biological diversity and the natural processes that sustain life" distinguishes the Earth Charter from most other global ethics declarations. The Global Ecological Integrity Group under the leadership of Laura Westra has documented the scientific and ethical justification for the principle of ecological integrity ${ }^{11}$ and proposed ways to firmly institutionalize it in international law and policy. ${ }^{12}$ How can these arguments be moved further into the mainstream of scientific discussion, which currently emphasizes historical dynamism, contingency and resilience? And most urgently, how can the principle be effectively implemented in international law and public policy?

(3) What ethical justification can we give for the legal recognition and enforcement of the "rights of sentient animals," "Nature," "Pachamama" or "Mother Earth"? The Earth Charter does not affirm the rights of nature. But the highly influential and widely supported People's Sustainability Treaty on the Rights of Mother Earth, which comes out of indigenous movements in South America, makes strong claims for them.

(4) In light of the cascade of post-9/11 wars and military conflicts, which have brought such damage and suffering to the planet and its peoples, Principle 16 - "Promote a culture of tolerance, nonviolence and peace" - is the weakest, least referenced section of the Earth Charter. We need strong, transformative ethical guidance on how to achieve comprehensive international security and peace. And it must be the kind of guidance that can challenge the ambitions for "full spectrum dominance" of the United States. This is a virtually unexplored frontier for Earth Charter leadership today.

11 Klaus Bosselmann, The Principle of Sustainability: Transforming Law and Governance (Ashgate, 2008); Jack Manno, "Why the Global Ecological Integrity Group? The Rise, Decline and Rediscovery of a Radical Concept", in Laura Westra, Prue Taylor and Agnes Michelot (eds.), Confronting Ecological and Economic Collapse: Ecological Integrity for Law, Policy and Human Rights. (Routledge, 2013); Laura Westra, An Environmental Proposal for Ethics: The Principle of Integrity (Rowman Littlefield, 1994); and L. Westra, P. Miller, P.J. Karr, J.W. Rees and R.E. Ulanowicz, "Ecological integrity and the aims of the Global Ecological Integrity Project", in Reed F. Noss, Laura Westra and David Pimentel (eds.), Ecological Integrity: Integrating Environment, Conservation and Health (Island Press, 2000).

12 Laura Westra, Prue Taylor and Agnes Michelot, Confronting Ecological and Economic Collapse: Ecological integrity for law, policy and human rights (Routledge, 2013). 
(5) To the best of my knowledge, no one acting in a public capacity as an Earth Charter spokesperson has taken a stand on any particular issue since the launch of the Charter in 2000. Although Earth Charter Commission members and supporters have no doubt joined and endorsed efforts such as 350.org to halt climate change, or called to account the policies of governments such as the invasion of Iraq by the United States in 2003 or the closing of the offices of the Pachamama Foundation in Ecuador in 2013, there is no clear prophetic voice speaking on behalf of the Earth Charter for major issues of public policy. This risks the impression that the principles of the Earth Charter are remote from the most urgent and pressing issues of the real world. Professor Nicholas Robinson writes: "For the Earth Charter to move from the periphery to the core of decision-making and governance, human beings and decision-makers need to see its relevance to the environmental and social crisis of the moment." 13 This observation holds true in reference not only to the great global issues of our time, but also to how these issues play themselves out in concrete places. Obviously, no single civil society organization can be expected to pass judgment on the myriad ways the many nations, corporations, armies and wealthy and powerful elites of the world breach Earth Charter principles; but without any paradigmatic examples or precedents to follow - especially examples that call to account the most powerful geopolitical agencies on the planet - there is insufficient ethical inspiration to galvanize a transformative international civil society movement. Our response to what happens on the ground in specific places is the acid test of the adequacy of our principles and whether the principles to which we give lip service are in truth the principles we follow.

(6) We are engaged in a long-term project to modify the underlying constitutive rule basis of modern civilization and to develop new modes of local as well as transnational governance. Central to the renewed dialogue of the Earth Charter must be a critical retrieval of the post-Second World War debates regarding the constitution of international law and governance and close study of proposals regarding what new world constitution is necessary and ethically justified in the twenty-first century.

(7) The Earth Charter has been "endorsed" by thousands of organizations and individuals across the world. But what does it mean to endorse the Earth Charter? What obligations does it entail? What accountability is

13 Nickolas Robinson, "Foreword" in Klaus Bosselmann and J. Ronald Engel (eds.), The Earth Charter: A Framework for Global Governance (Kit Publishers, 2010) 10. 
there? In 2004 the World Conservation Union overwhelmingly endorsed the Earth Charter as an "ethical guide to programme and policy." In 2012 we found it difficult to hold the International Union for Conservation of Nature leadership accountable to the Earth Charter at the 2012 World Conservation Congress when a consortium of Korean and international environmental, pro-democracy and peace groups asked for a full investigation and ethical debate on the ecological and social impact of the construction of a naval base at Gangjeong Village on Jeju Island, famously known throughout the Pacific as the "Island of Peace." 14 I have argued the need for a covenantal dimension to ethical movements for global citizenship. ${ }^{15}$ Without moral integrity, congruence of words and actions, and solidarity among persons devoting their lives to the "great work," often in the face of corruption and violent repressive opposition, there is no chance of significant social change.

(8) The principle of "common but differentiated responsibilities" is based on the ontological premise that we realize our humanity together because the fullness of humanity comes not from the adding of differences, but from the exchange and communion between them. If we are serious about this principle - sometimes translated as "situated universalism" or "rooted cosmopolitanism" - we are obligated to challenge every community throughout the world to draft an "ethical declaration" detailing its specific ethical responsibilities in light of the needs and strengths of its particular biocultural region and in the context of the special contributions it can make to our shared task of implementing the Earth Charter across the planet. These local or regional ethical declarations would be the pillars for a new constitution of global governance.

(9) How can we organize an international alliance of communities and organizations with sufficient political power to move the world system toward the implementation of Earth Charter principles? It will not happen by persuasion or non-violent protest alone. This is perhaps the single greatest challenge we must meet and we have barely begun to think through what is required to meet it.

(10) How are we to understand "democracy"? On the one hand, democracy and neoliberalism and militarism are now joined at the hip in the dominant ideology of our time. On the other hand, virtually every

14 Koohan Paik and Jerry Mander, "On the Front Lines of a New Pacific War" The Nation, December 14, 2012, www.thenation.com/article/171767/front-lines-new -pacific-war.

15 Engel, above n.1. See also J. Ronald Engel, "The Earth Charter as a New Covenant for Democracy" in Klaus Bosselmann and J. Ronald Engel (eds.), The Earth Charter: A Framework for Global Governance (KIT Publishers, 2010). 
progressive global ethics declaration of our age, including the Earth Charter, assumes the democratic principle. We can realize the promise of what is alternately referred to as true democracy, spiritual democracy, authentic democracy, substantive democracy, thick democracy, green democracy, Ecoglasnost, ecological democracy or Earth Democracy. Global ethicists and activists such Leonardo Boff, Klaus Bosselmann, Peter D. Burdon, Judith Coons, Cormac Cullinan, David Korten, Ashish Kothari, Francis Moore Lappe, Michael Lerner, Leslie Muray, Steven Rockefeller, Vandana Shiva, Sulak Sivaraska and Vik Muniz share with me the view that Earth Democracy is an emergent world faith. Boff speaks of how:

ecologico-social democracy accepts not only human beings as its components but every part of nature, especially living species [all of whom] are citizens, subject to rights, respected as others, in their own otherness, in their own existence, in their own life, and in their communion with us and with our fate and their future. . . fellowship with the whole of creation in its infinite grandeur, infinite smallness, and infinite variety. ${ }^{16}$

"Earth Democracy" is our chosen name for "living in the truth" of the ontological vision and world historical cause of the new axial age. It is a protean metaphor (Earth $=$ democracy) that bridges the differences of humans and nature by embracing the intrinsic values of each and a rich metaphoric complex of relationships such as liberty, equality and solidarity that support the ongoing creative evolution of these intrinsic values. Thus, Earth Democracy is a symphony; a dance; a patchwork quilt; a council ring; a string or necklace or wampum belt of various colored or shaped beads; a covenant of persons who have pledged themselves to one another and to the greater community of life of which they are a part.

Such a proposition requires extensive debate and inquiry, for it goes to the core of whether contemporary political and religious rhetoric can capture the promise of the new axial age and lead us toward a transformation in the reigning global order. What sacred narrative grounds the promise of Earth Democracy? What theological understanding justifies it as a redemptive path? If this is not a credible way of stating our axial faith, what is? What, in conclusion, we might ask, could be more motivating, interesting, ennobling, more inherently worthwhile, than engaging with colleagues and partners in the Earth Charter movement in discussions such as these regarding the ethical responsibilities incumbent upon our species if the world is to enter a new axial

16 Leonardo Boff, Ecology and Liberation: A New Paradigm (Orbis Books, 1993). 
age? What greater satisfaction than contributing to the creation a new order of existence that brings us into greater alignment with what is truly and everlastingly good?

I believe that the hope for the world, the hope for the realization of the promise of the Earth Charter, lies in social movements. By their willingness to now join together in vigorous international discussion of the kind proposed here, and by their determination to take ethically grounded political leadership, we will build an international movement with the power to usher in a new era of global governance in which justice and peace prevail and the ecological integrity of the planet is restored and sustained. 